\title{
Management of the Spread of Tomato spotted wilt virus in Tobacco Crops with Insecticides Based on Estimates of Thrips Infestation and Virus Incidence
}

\author{
E. K. Chatzivassiliou, Democritus University of Thrace, Department of Agricultural Development, Plant Pathology \\ Laboratory, Pantazidou 193, 68200 N. Orestiada, Greece
}

\begin{abstract}
Chatzivassiliou, E. K. 2008. Management of the spread of Tomato spotted wilt virus in tobacco crops with insecticides based on estimates of thrips infestation and virus incidence. Plant Dis. 92:1012-1020.

Tomato spotted wilt virus (TSWV) causes serious losses in the tobacco-producing areas of northern Greece. Following a destructive epidemic of TSWV in the prefecture of Kilkis in 2003, a coordinated disease management scheme was developed in collaboration with the local tobacco farmers' associations on 1,000 ha in 2004 and 500 ha in 2005 of tobacco crops of the cv. Virginia. Insecticides first were evaluated for efficiency to control Thrips tabaci, the only TSWV vector present in tobacco crops in Greece. Field data on T. tabaci infestation, population fluctuation, and TSWV incidence were used to coordinate insecticide applications. T. tabaci overwinters in the soil covered by wild flora close to infested fields. The first adults of each season were recorded on blue sticky traps in week 13 and viruliferous individuals were found on weeds close to the tobacco fields in week 16 of both years. Tobacco seedlings were protected against thrips by a preventive drench application of carbofuran to soil in seedling beds, followed by two methomyl and one malathion foliage applications. To achieve an effective decrease of primary inoculum in the fields, malathion was applied to weeds on the field borders before transplanting the tobacco seedlings. In the tobacco crops, carbofuran was applied directly after transplanting. Early transplanted (week 19 to 20) seedlings were sprayed with methomyl. Subsequently, two rounds of foliar applications were started in week 23, consisting of cypermethrin, followed by malathion and methomyl, followed by one or two malathion sprays. At transplanting (week 19 to 23 or 22 in 2004 or 2005, respectively), $340 \pm 160$ (mean + standard deviation, $n=4$ weeks) and $230 \pm 130(n=3)$ T. tabaci individuals per trap were recorded in 2004 and 2005, respectively, and $52 \%$ of the thrips trapped in the neighboring flora in 2004 were TSWV infected. Afterwards, T. tabaci populations did not increase significantly until harvest (up to 350 individuals were counted per trap). In a control field of an oriental tobacco cultivar in which no insecticides were applied, up to 5,000 and 3,300 thrips were found per trap in 2004 and 2005, respectively. The final incidence of tobacco plants with TSWV infection fluctuated from 10 to $20 \%$ in the Virginia tobacco crops whereas, in the control crop, it was 60 and $85 \%$ in 2004 and 2005, respectively. This study showed that a well-coordinated collective plan based on data on infection pressure by TSWV and the vector population fluctuation during the growing season can represent an effective way of combating epidemics in tobacco.
\end{abstract}

Additional keywords: epidemiology, Thripidae, tobacco thrips

Tomato spotted wilt virus (TSWV) (Bunyaviridae: Tospovirus) is one of the most destructive plant viruses worldwide (23). The virus is spread by seven thrips species belonging to the genera Thrips and Frankliniella (Thysanoptera: Thripidae; 58) to hundreds of plant species $(42,44)$. Among the cultivated hosts, tobacco (Nicotiana tabacum L.) crops suffer from destructive TSWV epidemics associated with the vector Thrips tabaci Lindeman in Eastern Europe and the Balkan countries (7) and Frankliniella

Corresponding author: E. K. Chatzivassiliou E-mail: echatz@agro.duth.gr

Accepted for publication 28 January 2008.

doi:10.1094/PDIS-92-7-1012

(C) 2008 The American Phytopathological Society in early August, and highly viruliferous thrips populations developed on the diseased plants by the end of the season.

Management strategies that use an interdisciplinary approach based on disease epidemiology compose the only effective way to combat such TSWV epidemics (30). A previous study on the dynamics of TSWV spread showed that development of infection in tobacco crops could be attributed mainly to primary infections by migrating vectors (13). Reduction of external virus sources and prevention of development of the vector populations are important for effective control using an integrated management program (30). Seventy-two weed plant species may harbor external virus sources for tobacco crops in Greece $(9,11)$. In temperate areas, overwintering thrips can form a significant source of inoculum for field crops grown in the summer (29). Additionally, seasonal fluctuations in thrips vector populations in relation to crop growth affects spread of the virus $(15,18,21,37$, 39,47). T. tabaci adults can transmit TSWV to tobacco in short feeding probes, and they remain viruliferous for life (10). It is likely that thrips cannot acquire a mortal dose of insecticide in a short puncture in which a thrips can transmit TSWV (45). Accumulation of insecticides acquired in successive punctures may finally kill the thrips. Notwithstanding this delayed effect, the use of insecticides against migrating vectors is still of primary importance for the management of TSWV spread $(17,20,24,41,48)$.

This article presents the results of a coordinated disease management plan applied in collaboration with the local tobacco farmers' associations in 2004 and 2005 in order to prevent a TSWV epidemic in the tobacco crops in the Kilkis region in Greece. Detailed studies, including identification of the overwintering sites of the thrips vector and insecticide evaluations in laboratory experiments, preceded application of the management plan. Data concerning thrips population fluctuations and vector presence as well as virus incidence in the crops were recorded continuously during the cropping season, and used to set the dates at which the sprays were applied.

\section{MATERIALS AND METHODS}

Evaluation of insecticides against $\boldsymbol{T}$. tabaci. An arrhenotokous population of $T$. tabaci was collected from a tobacco plant in a tobacco crop highly infected with 
TSWV in the area inspected in the Kilkis prefecture during the TSWV epidemic of 2003. This population was reared on leek for three generations and then transferred to tobacco plants of $\mathrm{cv}$. Basmas (an oriental $N$. tabacum cultivar) in thrips-proof cages held at $25 \pm 1{ }^{\circ} \mathrm{C}$ with a 16 -h photoperiod per day.

The effectiveness of insecticides registered to control thrips in tobacco crops in Greece (Hellenic Ministry of Rural Development and Food; Table 1) was evaluated in laboratory experiments using the local $T$. tabaci population. The carbamate insecticides carbofuran and methomyl were evaluated as soil-applied (drenched) insecticides. The nicotinoid insecticide imidacloprid was included in this study because it is widely used as a soil drench against aphids in tobacco crops in Greece. Methomyl; the organophosphorus insecticides dimethoate, malathion, methamidophos, and methidathion; and the pyrethroid insecticide cypermethrin were tested as foliar-applied insecticides. Insecticides were tested using the mean rates recommended by the registrants (Table 1), and were applied as aqueous suspensions to plants of the cv. Virginia that had two to four true leaves. When necessary, the rate was adjusted to a standard volume of 750 or 50 liters of water per 10 ha, which is used routinely by farmers in Greece for soil or foliar applications of insecticides, respectively (Table 1). Insecticide solutions were applied as a soil drench directly at the base of plants, whereas foliar insecticides were applied using a 2-liter handpressure sprayer (Venus; Bulb Center S.A., Athens, Greece).

Effectiveness of the insecticides for control of thrips was evaluated by placing 10 1- to 4-day-old T. tabaci females on a treated tobacco leaf. Each leaf was placed on $1 \%$ Bacto agar (Scharlau Microbiology, Barcelona, Spain) containing 3\% benzimidazole (Sigma-Aldrich Steinheim, Germany) in 9.5-cm-diameter petri dishes. A hole $3 \mathrm{~cm}$ in diameter in the lid of each dish was closed with a 100-mesh nylon screen for ventilation. After placing thrips on the leaves, the dishes were sealed with
Parafilm (Sigma-Aldrich) and kept in a growth chamber at $25 \pm 1^{\circ} \mathrm{C}$ and $16 \mathrm{~h}$ of light per day. Thrips survival was recorded on leaves taken from the treated plants after 1 day and, subsequently, at 5-day intervals until 30 days after application of the soil-applied insecticides. Foliar-applied insecticides were evaluated on sprayed leaves detached from the treated plants at 2-day intervals until 10 days after spraying, and on the nonsprayed top (apical) leaves that developed in the 10-day period. Each insecticide and day post application was tested in five replications. Thrips confined on leaves of nontreated plants were used as a control treatment. When surviving female thrips were encountered, the infested tobacco leaves were kept on agar at $25 \pm 1{ }^{\circ} \mathrm{C}$ and inspected 6 days later for emerged larvae. The sex ratio of these larvae was recorded by rearing the larvae into adults on an untreated tobacco leaf of the cv. Virginia.

Statistical analysis. To compare efficiency of the insecticides for thrips control on different days after application, an angular transformation was applied to the incidence (percentage) of T. tabaci surviving; percentage values of 0 or 100 were converted to $25 / n$ or $100-25 / n$ (where $n=$ 5 repeats), respectively. The transformed data were subjected to analysis of variance (ANOVA) and the means were compared using least significant difference (LSD) values at $P<0.05$, with the statistical program SPSS (SPSS Inc., Chicago).

Thrips infestation and TSWV incidence in the field. A thrips management scheme was executed in an area extending over 1,000 ha in 2004 and over 500 ha in 2005 with crops of the tobacco cv. Virginia in the Paionia area of the Kilkis prefecture of Greece. This area included fields onwned by more than 300 farmers in 2004 and 100 farmers in 2005. A similarly sized area of cotton and wheat crops scattered between the tobacco crops was not included in the spray program each year. The seasonal thrips dynamics, TSWV presence, and efficacy of insecticide applications for the control of $T$. tabaci populations and TSWV spread were recorded every week in 10 seedbeds of two seedling production systems (5 outdoor soil seedbeds raised $10 \mathrm{~cm}$ above the ground and 5 greenhouse 'float' systems in which pelleted tobacco seed were seeded directly on peat in polystyrene trays floated on a pool of water enriched with nutrients; 4) and in 10 fields of the tobacco cv. Virginia. As a control treatment, the thrips population size and TSWV incidence were monitored for an oriental tobacco cv. Basmas in one seedbed in 2004 and one tobacco field in both years. Foliarapplied insecticides were not used in the control seedbed or the control fields.

Tobacco seedbeds were established 1 month after fumigation of the soil with methyl bromide (Methyl BromideAtochem 98 Gas; ELF Atochem SA, FR) in the first 2 weeks of March of both years. Each soil seedbed was covered with a low plastic tunnel until the tobacco seedlings had emerged, while float systems were established in greenhouses. Virginia tobacco seedlings were transplanted into the fields included in the area under study from the beginning of May (week 19) until early June (week 22 in 2004 and week 21 in 2005), at a spacing of $45 \mathrm{~cm}$ in the row and $90 \mathrm{~cm}$ between adjacent rows. The spacing was 10 and $40 \mathrm{~cm}$, respectively, for the oriental tobacco control crops. Harvest periods lasted for 2 months, starting for the oriental and Virginia crops in week 28 and week 30, respectively, in 2004 but a week earlier for both cultivars in 2005.

Prior to tobacco seedling production, soil and plant material from 10 tobacco fields that had a history of high TSWV incidence and thrips infestation in 2003 were sampled for the presence of overwintering thrips. Soil was sampled to a depth of $30 \mathrm{~cm}$ in each tobacco field as well as from the borders of the fields in midFebruary, and kept for 1 month in a cold room $\left(5^{\circ} \mathrm{C}\right)$. The soil sample from each field was tested as a planting substrate for five tobacco seedlings with two to four true leaves after mixing the soil with sand and placing the mixture and the plants in thrips-proof cages at $25^{\circ} \mathrm{C}$. The plants were monitored for the presence of thrips

Table 1. Insecticides evaluated against Thrips tabaci females in laboratory experiments for control of the tospovirus Tomato spotted wilt virus in tobacco crops in Greece

\begin{tabular}{llcc}
\hline $\begin{array}{l}\text { Active ingredient } \\
\text { chemical classification) }^{\mathbf{a}}\end{array}$ & \multicolumn{1}{c}{ Trade name, formulation, and registrant } & $\begin{array}{c}\text { Suggested rate } \\
\text { (label instructions) }\end{array}$ & $\begin{array}{c}\text { Application rate } \\
(\mathbf{m l} / \text { liter) }\end{array}$ \\
\hline Carbofuran (C) & Furadan 35 SC, FMC Hellas Ltd. & $400 \mathrm{ml} / 10 \mathrm{ha}$ & $0.54(\mathrm{~S})$ \\
Cypermethrine (P) & Cypermethrine Ellagret 10 EC, Ellagret SA, GR & $60 \mathrm{ml} / 10 \mathrm{ha}$ & $1.2(\mathrm{~F})$ \\
Dimethoate (O) & Dimethoate Ypsilon 40 EC, Ypsilon SA, GR & $75-150 \mathrm{ml} / 100$ liters of water & $1.13(\mathrm{~F})$ \\
Imidacloprid (N) & Confidor 20 SL, Bayer CropScience Hellas SA & $50-100 \mathrm{ml} / 10 \mathrm{ha}$ & $0.1(\mathrm{~S})$ \\
Malathion (O) & Polimal 50 EC, Agrotechnica SA, GR & $100-200 \mathrm{ml} / 100$ liters of water & $1.5(\mathrm{~F})$ \\
Methamidophos (O) & Monitor 60 SL, Geofarm SA, GR & $75-100 \mathrm{ml} / 100$ liters of water & $1.75(\mathrm{~F})$ \\
Methidathion (O) & Methidacide 40 EC, Ypsilon SA, GR & $75-100 \mathrm{ml} / 100$ liters of water & $0.88(\mathrm{~F})$ \\
Methomyl (C) & Methomyl Makhteshim 20 SL, Alfa Agricultural Supplies SA, GR & $360 \mathrm{ml} / 10 \mathrm{ha}(\mathrm{S})$ & $0.48(\mathrm{~S})$ \\
& & $180-270 \mathrm{ml} / 10 \mathrm{ha}(\mathrm{F})$ & $4.5(\mathrm{~F})$ \\
\hline
\end{tabular}

${ }^{a}$ Chemical classification of active ingredients indicated as follows: $\mathrm{C}=$ carbamate, $\mathrm{O}=$ organophosphorus, $\mathrm{P}=$ pyrethroid, and $\mathrm{N}=$ nicotinoid.

${ }^{\mathrm{b}}$ Rate of application in milliliters of product per liter of water. Type of application: $\mathrm{S}=$ soil drench, application through the irrigation water; and $\mathrm{F}=$ foliar spray. 
every 5 days for 1 month. Thrips were sampled from wheat and several weed species in mid-February 2004 and in the beginning of March 2004 by tapping the plants onto white paper. In total, 50 wheat seedlings and 20 weed plants were collected from each field in each sampling date. Adult thrips found on the plants were tested for the ability to infest tobacco by placing the thrips on tobacco leaves in petri dishes for 2 days. The leaves then were examined for the presence of thrips feeding injury.

Every week, 100 randomly selected tobacco leaves were collected from each of the selected seedbeds and float systems and 50 leaves from the 10 selected fields, and visually examined for TSWV symptoms as well as thrips infestation. Additionally, on average, 30 weed plants of the species present were collected randomly every week from each selected seedbed, float system, and field until 1 month after transplanting. Those weeds were examined for the presence of thrips by tapping the plants onto white paper, and tested for TSWV infection by enzyme-linked immunosorbent assay (ELISA). Adult thrips collected on the plants were tested for the ability to infest tobacco, as described above. Subsequently, live thrips were tested individually for TSWV infectivity using a petunia leaf disc method (55). Development of necrotic local lesions on the petunia leaf discs was indicative of the presence of TSWV viruliferous thrips (55). Thrips were collected from 28 weed species each year, and 686 or 354 live thrips were tested in this manner in 2004 or 2005, respectively.

Five tobacco seedlings sown in the laboratory were transplanted among the wild flora on the borders of each of the $10 \mathrm{se}$ lected Virginia tobacco fields in March, in order to serve as 'trap' plants for TSWV and thrips (30). At each sampling date, these plants were inspected for injuries from thrips feeding and symptoms of TSWV infection. Thrips populations were monitored weekly, starting 1 week after sowing the tobacco. Thrips population fluctuation was recorded in each seedbed or float system and in the field using two 10-by-40-cm blue sticky traps (Horiver TR; Koppert B.V., NL). Traps were placed on sticks 10 to $20 \mathrm{~cm}$ above the tobacco leaf canopy and in the neighboring wild flora. Thrips present on a randomly chosen portion of the trap surface, consisting of one-sixth of the total trap area, were removed using white spirit (Vechro S.A, Thiva, Greece) as a thinner, and the $T$. tabaci individuals were identified and counted (40).

Double-antibody sandwich ELISA tests. Tobacco leaves showing symptoms of TSWV infection and weeds were tested by double-antibody sandwich (DAS)ELISA with polyclonal antibodies (1 $\mu \mathrm{g} / \mathrm{ml}$ ) raised against the nucleocapsid (N) protein of TSWV (BR-01, supplied by Dr D. Peters, WAU, NL) (59). Each leaf extract was prepared by grinding $15 \mathrm{mg}$ of leaf tissue in $1 \mathrm{ml}$ of phosphate-buffered saline-Tween $(0.14 \mathrm{M} \mathrm{NaCl}, 1 \mathrm{mM}$ $\mathrm{KH}_{2} \mathrm{PO}_{4}, 8 \mathrm{mM} \mathrm{Na} \mathrm{HPO}_{4}, 2.5 \mathrm{mM} \mathrm{KCl}$, and $0.05 \%$ Tween 20 ) containing $2 \%$ polyvinylpyrollidone (molecular weight approximately 6,000 ) and $0.2 \%$ bovine serum albumin. The ELISA well absorbance values were read on a Stat Fax 2100 microplate reader (Awareness Technology, Florida) at $405 \mathrm{~nm}$, and were corrected for blank wells containing only extraction buffer in the sample incubation step. Samples with ELISA values higher than three times that of healthy control plants (weeds or tobacco, depending on the sample) were considered infected.

The insecticide application scheme. The insecticide application scheme was aimed at reducing primary inoculum from overwintering thrips as well as thrips that develop during the cropping period. The insecticides used and the dates of application were chosen so that scheduled field work also could be performed according to the restricted entry intervals (REI) following each insecticide application. Carbofuran was selected as a soil-applied (drenched) insecticide, due to the high and long-lasting action recorded in our laboratory studies. Applications were timed to protect young tobacco seedlings preventatively in the seedbeds and in the first weeks after transplanting seedlings into the fields. Further protection of the plants was achieved using different classes of insecticides to reduce the risk of developing insecticide resistance in the thrips populations (30). The pyrethroid cypermethrin and the carbamate methomyl were included as foliar-applied insecticides. Malathion, an organophosphate, although the least effective of the products used in our tests, was selected based on the label information, due to the unlimited numbers of applications that are allowed to be made in a tobacco cropping period in Greece and the short REI (24), in order for the farmers to be able to perform necessary field work (fertilization and topping) or harvest safely.

To determine the dates of insecticide applications in the tobacco crops, data concerning thrips populations collected during the cropping period as well as insecticide efficacy for T. tabaci obtained in the laboratory trials were used. The increase from 5 to $52 \%$ of viruliferous thrips in weeds and the presence of thrips feeding injury on the tobacco trap plants determined the first insecticide spray in the seedbeds. Afterwards, thrips populations were high in the untreated controls in both years; therefore, foliar-insecticide applications in the fields started as soon as tobacco seedlings recovered from transplanting shock. The intervals between successive applications ranged from 5 to
15 days, depending on the insecticide's residual activity and plant age. The first round of foliar applications (cypermethrine followed by malathion and then methomyl), intended to protect tobacco seedlings until 1.5 month after transplanting, thought to be the most critical period for TSWV infections $(34,36,55)$, were performed in about weekly intervals. Malathion was followed by the shortest interval (5 days) between applications. The occurrence of symptoms of thrips feeding injury on the tobacco leaves sampled in any of the 10 Virginia crops was a signal to carry out an insecticide application.

Seedlings were protected against the first thrips flight and, thus, spread of TSWV by a preventive soil application of carbofuran to the open-air seedbeds when the plants had four true leaves (week 14 or 15). One foliar spray with methomyl was used at the same time in the greenhouse float systems of the tobacco seedling production, because carbofuran is not registered for use in float systems (24). Two methomyl foliar applications were made to the seedbeds in the next 2 weeks when viruliferous thrips were recorded on weeds. One or two malathion applications in seedbeds, used for early or late plantings, respectively, subsequently were performed at 5 day intervals until transplanting. In two of the soil seedbeds in which thrips populations were recorded, farmers also applied an imidacloprid foliar spray in mid-May for aphid control.

Malathion was applied to flora in a 5-mwide zone in the borders around each Virginia tobacco field 2 days before transplanting. During transplanting (weeks 19 to 22), carbofuran was drenched in the field. For the early-planted crops (weeks 19 to 20), methomyl was sprayed about 2 weeks after transplanting, shortly after the first increase of numbers of thrips caught in the traps (week 21 in 2004 and week 20 in 2005). Subsequently, about 10 days after the end of all transplanting operations, one round of applications was made with cypermethrine followed by malathion and then methomyl at approximately weekly intervals to all plantings. Weeds surrounding the fields or seedbeds were included in the area sprayed. The sprays were delayed in 2005 due to heavy rainfalls; therefore, the applications were made during weeks 23 and 24 in both years. A second round of these insecticides was applied 15 days later in July and August, respectively. The whole 1,000 ha of the study was sprayed in a period of 6 days for each application, whereas the 500 ha included in the 2005 study was sprayed in 3 days. Subsequently, two and one additional malathion sprays were applied by each farmer in 2004 and 2005, respectively. Finally, in 2004, malathion was applied by most farmers to the tobacco stalks after harvest and before the incorporation of the crop residues into the soil. 


\section{RESULTS}

Evaluation of insecticides against $\boldsymbol{T}$. tabaci. Based on the ANOVAs, insecticides and the time interval after application at which evaluations were done had a highly significant $(P=0.001)$ effect on survival of $T$. tabaci females on tobacco leaves treated either with soil-applied insecticides (insecticide active ingredient: $F$ $=124.51, \mathrm{df}=3,80$; time after application: $F=18.83$, df $=4,80$ ) or foliar-applied insecticides (insecticide active ingredient: $F=333.34$, df $=6,198$; time after application: $F=53.88 \mathrm{df}=5,168$ ). Two-way ANOVAs showed that interaction of time after application with the soil-applied $(F=$ 7.22, df $=12,80)$ and foliar-applied $(F=$ $7.09, \mathrm{df}=30,168$ ) insecticides on $T$. tabaci survival was significant at $P \leq 0.001$.

When the carbamates carbofuran and methomyl and the nicotinoid imidacloprid were evaluated as soil-applied (drenched) insecticides, no thrips survived on carbofuran-treated plants at almost any of the times monitored post application (Fig. 1). Surviving T. tabaci females $(22 \%)$ were found only on leaves 20 days post application (dpa) for carbamate. In the field, carbofuran-treated plants in 2 of the 10 inspected fields were found to be infested with thrips 15 dpa On imidacloprid-treated leaves, $24 \%$ of $T$. tabaci females survived 1 day p.a., after which $T$. tabaci numbers increased to $70 \%$ by 5 days (Fig. 1). On methomyl-treated leaves, a lower survival rate $(6 \%)$ was recorded 5 dpa compared with imidacloprid; the latter two insecticides did not differ significantly in effectiveness against $T$. tabaci when used as soil drenches (Fig. 1).

When foliar-applied insecticides were evaluated against $T$. tabaci, the best performance $(0 \%$ survival) was recorded for the pyrethroid cypermethrin and the organophosphate methamidophos. The survival on the leaves treated with those insecticides was the lowest even up to 10 dpa. On the leaves sprayed with the carbamate methomyl or the organophosphate dimethoate, a survival of $20 \%$ was recorded in the first $10 \mathrm{dpa}$. Almost no thrips could survive on the top leaves of the plants that developed 10 days after foliar applications of cypermethrin (Fig. 2). On malathion-treated leaves, the lowest survival $(14 \%)$ was recorded up to the first 2 dpa. On methidathion-treated leaves, no thrips survived when tested 2 dpa. Survival increased to more than $50 \%$ after $10 \mathrm{dpa}$ for malathion and methidathion application (Fig. 2). More than $85 \%$ of the T. tabaci females tested on leaves of the nontreated tobacco plants survived in the tests of the soil- or foliar- applied insecticides (Figs. 1 and 2).

In the insecticide evaluation tests, thrips did not produce any offspring on cypermethrin-treated tobacco leaves (data not shown). However, larvae were observed on the nonsprayed top leaves of all plants treated with an insecticide tested in this study (i.e., malathion, methidathion, methomyl, and dimethoate), particularly those treatments for which females survived on the leaves sprayed (Fig. 1). The sex ratio (males/females $[\mathrm{m} / \mathrm{f}]$ ) of the larvae that developed to adults ranged from $1 / 3$ to $1 / 5$ for most of the insecticides tested. An increased number of males $(1 / 1.2, \mathrm{~m} / \mathrm{f})$ were encountered on leaves of plants treated with carbofuran and imidacloprid as soil drenches (data not shown).

Thrips infestation and TSWV incidence in fields. When soil was sampled from fields used for tobacco cropping in 2003 , significantly more thrips were found in soil sampled at the borders of the fields $(3.2 \pm 1.2$, mean + standard deviation [SD], $n=10$ fields) than in soil samples collected in the center of each field $(0.8 \pm$ 1). The thrips infesting tobacco seedlings planted into these soil samples all were identified as T. tabaci. Nine thrips specimens were found on wheat or weed plants sampled early in March, but these thrips did not feed on tobacco leaves when tested.

Anthemis arvensis, Capsella bursapastoris, Cardaria draba, Chamomila recutita, Convolvulus aviculare, Galium aparine, Malva neglecta, Papaver rhoeas, Rumex sp., and Sinapis arvensis were the main weed species collected on the borders of the tobacco seedbeds inspected for thrips infestation in both cropping seasons. Specimens of Alopecurus myosuroides, Amaranthus retroflexus, Aristolochia clematis, Artemisia vulgaris, Chenopodium amaranticolor, Cichorium intybus, Conyza canadensis, Consolida regalis, Hypericum perforatum, Lactuca seriolla, Lamium purpureum, Mentha spp., Plantago lanceolata, Polygonum aviculare, Scabiosa tenuis, Sonchus spp., Sorgum halepense, Vicia

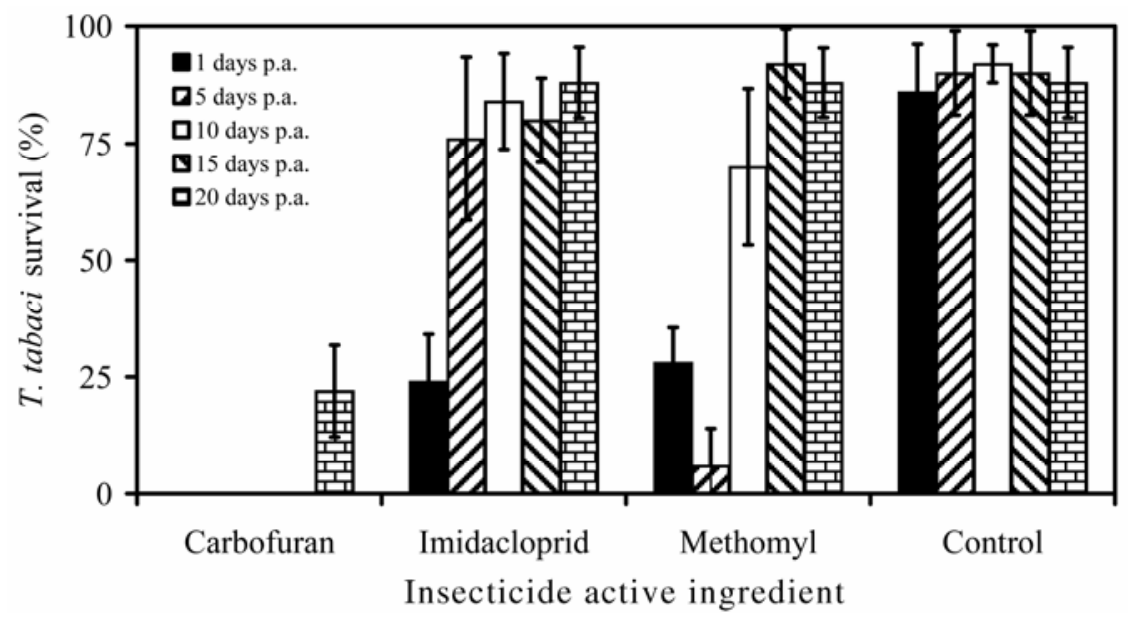

Fig. 1. Survival (\%) of Thrips tabaci after transferring 10 0- to 4-day-old females on tobacco leaves of the cv. Virginia (sampled at different intervals) from plants treated with carbofuran, imidacloprid, or methomyl as soil drenches at different days post application (p.a.), with five replications of each treatment combination. Control plants were not treated with an insecticide. Error bars give the standard deviation.

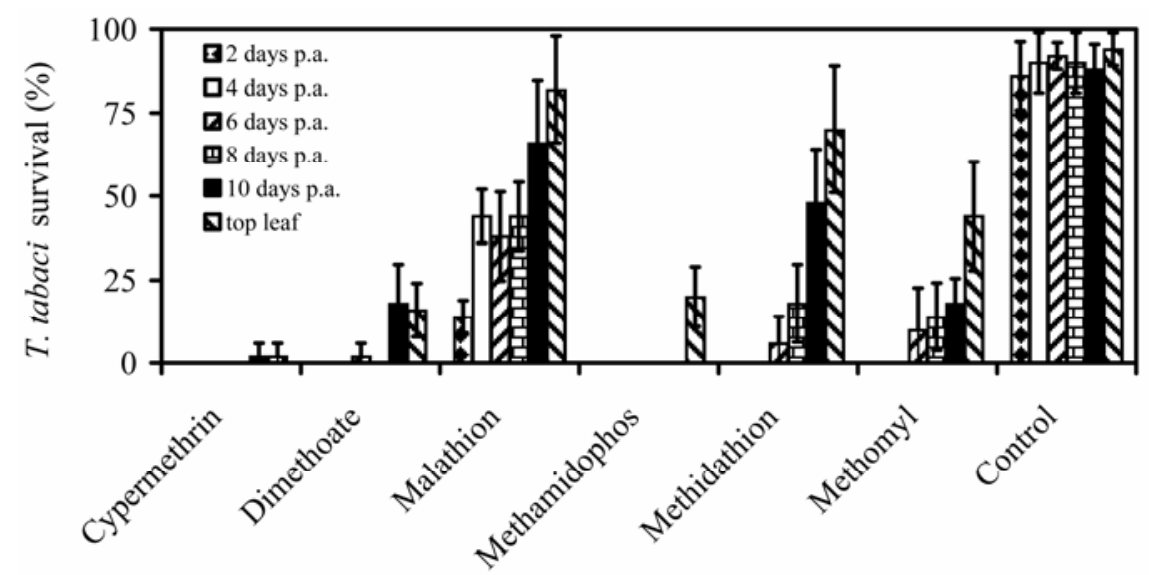

Insecticide active ingredient

Fig. 2. Survival (\%) of Thrips tabaci after transferring 10 0- to 4-day-old females on leaves of tobacco plants of the cv. Virginia at different intervals after spraying the plants with cypermethrin, dimethoate, malathion, methamidophos, or methomyl, or on nonsprayed control plants, for five replications of each treatment combination. Top leaf represents the leaf that developed 10 days post application (p.a.) of appropriate insecticide to the lower leaves of each plant. Error bars give the standard deviation. 
spp., and Xanthium strumarium were collected from within and around the tobacco fields. TSWV-infected plants of Aristolochia clematis, Artemisia vulgaris, Cardaria draba, Chamomila recutita, Malva neglecta, and Papaver rhoeas were recorded in week 18 of 2004, and Sonchus spp., Cichorium intybus, and Vicia spp. in week 20 of the same year. TSWV-infected Cardaria draba plants also were recorded from week 15 onward in 2005.

In both years, some unidentified thrips were found on weed or wheat plants from mid-April (week 13). T. tabaci individuals, some of them $(5 \%)$ viruliferous, were found on flowering Cardaria draba and Chamomila recutita sampled close to the tobacco fields only late in April (week 15). In 2004, the first invasion of thrips on tobacco seedlings as well as on the trap tobacco plants in the borders of the fields was recorded 1 week later (week 16), and necrotic local spots and the first systemic symptoms of TSWV infection appeared a week later (week 17). A significantly high number of viruliferous $T$. tabaci individuals (52\%) and several nonviruliferous but nonidentified thrips larvae were encountered on those plant species in subsequent weeks in 2004. Following week 17, T. tabaci individuals were encountered

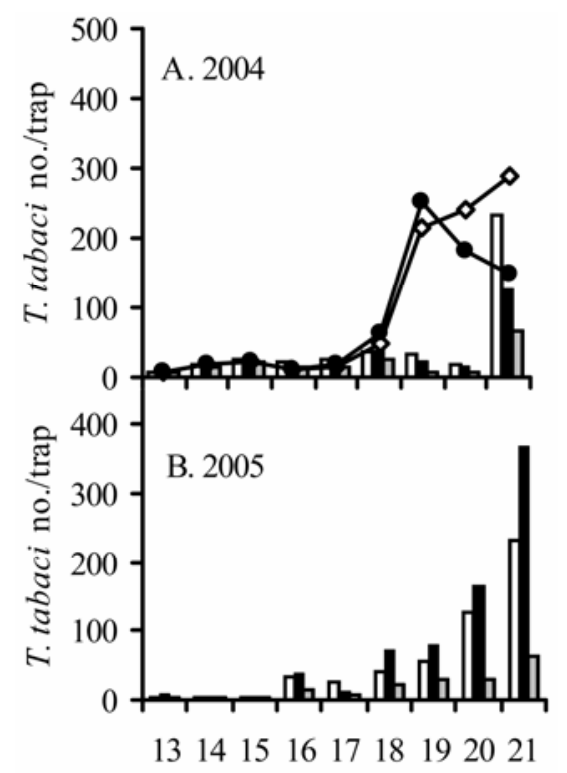

Week of the year

Fig. 3. Mean number of Thrips tabaci adults trapped on blue sticky traps in Nicotiana tabacum cv. Virginia seedbeds in the open air (soil, white columns), greenhouse (float system, striped columns), or in the neighboring flora (black columns) in A, 2004 and $\mathbf{B}, 2005$. A, Lines represent the numbers of $T$. tabaci individuals collected in the open soil seedbed of an oriental tobacco cultivar used as a control treatment in 2004 (black dots) or in the neighboring flora (white dots). B, No control treatment was included in 2005. Arrows indicate the dates at which insecticides were applied: 1, carbofuran or methomyl applied as soil drench; 2 and 3, methomyl sprays; and 4 and 5 , malathion sprays. not only on the two weed species but also on flowering plants of Hypericum perforatum, Xanthium strumarium, Vicia spp., Cichorium intybus, and Scabiosa tenuis, as well as on cotton plants cultivated in the area. The thrips collected on wheat plants did not survive on tobacco leaves. However, those thrips collected on the above weed species (mainly Chamomila recutita) growing within cereal fields accepted tobacco as a host.

The seasonal dynamics of the T. tabaci populations were similar in both years (Fig. 3). Adult thrips were first found on traps in seedbeds at the end of March (week 13; Fig. 3). A high increase in $T$. tabaci adults was observed in the control seedbed (from 48 to 216 adults/trap) and in weeds neighboring the seedbed (from 61 to 250 adults/trap) in mid-May (week 19 in 2004), just before transplanting the first tobacco seedlings (Fig. 3A). In the seedbeds or float systems, where insecticides were applied according to our management plan (a preventive drench application of carbofuran to soil seedbeds or a methomyl application to the float systems, followed by two methomyl and one malathion foliage applications), T. tabaci was kept under control until transplanting (weeks 19 to 21); an increase in thrips numbers (to an average of 200 thrips/trap) was noticed on the seedlings left in the seedbeds after the end of transplanting (week 21). In general, lower numbers of $T$. tabaci adults were found in traps in the greenhouse float systems $(14 \pm 6$ thrips/trap, mean $+\mathrm{SD}, n=8$ weeks) than in the open soil seedbeds ( 24 \pm 8 thrips/trap). In traps placed above the weed flora close to the seedbeds, $17 \pm 9$ and $36 \pm 30$ thrips/trap were recorded in 2004 and 2005, respectively. The number of T. tabaci adults trapped on the weeds was similar or higher compared with those trapped on the seedbeds in 2004 or 2005 , respectively (Fig. 3).

In 2004, T. tabaci was found on traps placed in all fields and on weeds close to the fields a month before transplanting (week 14; Fig. 4A). In 2005, the first thrips were recorded on traps on weeds in week 16 , and thrips numbers increased on traps within the fields only after transplantating the tobacco seedlings (weeks 19 to 21; Fig. 4B). At transplanting (week 19 to 23 in 2004 or 19 to 22 in 2005), $340 \pm 160$ (mean $+\mathrm{SD}, n=4$ weeks) and $230 \pm 130$ $(n=3)$ T. tabaci individuals per trap were recorded in 2004 and 2005, respectively. Thrips first were observed on plants in the sprayed tobacco crops in week 23 . In the control fields of oriental tobacco, two main peaks of $T$. tabaci numbers occurred in both years (Fig. 4). Thrips numbers were significantly higher in 2004 but fluctuated more in 2005 (Fig. 4). The first peak was recorded in late June $2004(2,700$ thrips/trap in week 25) and 2 weeks earlier (1,800 thrips/trap in week 22) in 2005; the second peak was in late July 2004 (5,000 thrips/trap in week 29) and in early August of 2005 (1,700 thrips/trap in week 30$)$. The population decreased after the last harvest of the control crop late in August 2005 (week 35), but some thrips were still developing on the leaves remaining on the tobacco stalks. In the Virginia tobacco fields in which insecticides were applied, T. tabaci numbers increased significantly (1,300 individuals/trap) only before the first foliar application in 2004; however, later, they were kept under control (only up to 250 or 350 individuals/trap in 2004 or 2005 , respectively) until the beginning of harvest (week 30 and week 29 in 2004 and 2005, respectively). During harvest, the tobacco thrips population increased through to mid-September (week 39 in 2004 and week 38 in 2005; Fig. 4A). In 2004, few $(7 \pm 2$, mean $+\mathrm{SD}, n=10$ fields) winged thrips were recorded in mid-November (week 45) on traps placed above the weeds.

TSWV incidence, as estimated by the number of TSWV-infected leaves when 50 randomly collected leaves from each field were tested by ELISA, reached 10 to $20 \%$ in August in the 10 Virginia tobacco fields included in the area of the application scheme in 2004 and 2005, respectively. In the control fields of the oriental tobacco, 85 and $60 \%$ of the plants became infected with TSWV in 2004 and 2005, respectively. The mean yield of the Virginia crops was 32 and 34 tons/ha in 2004 and 2005, respectively whereas, in the previous year with the severe epidemic (2003), approximately 20 ton/ha was harvested.

\section{DISCUSSION}

TSWV forms a serious threat for tobacco production in Greece (8), especially when environmental conditions favor development of the vector, T. tabaci. Different cultural and chemical control measures have been evaluated and used to control TSWV (17-20,25,41,54), and efficient integrated strategies combining different management practices have been developed $(14,48)$. This study presents an effort to manage TSWV spread by largescale insecticide applications against $T$. tabaci based on field data of virus incidence and vector presence on weeds and tobacco crops. The results show that a large reduction in disease incidence was obtained compared with the nontreated fields in a project in which tobacco seedbeds and fields were treated with various insecticides based on data on infection pressure by TSWV and the vector during the growing season.

Application of insecticides is an integral component of most TSWV and thrips control strategies (48). To develop an optimal application program for tobacco production in Greece, the efficacy of eight insecticides were evaluated against $T$. tabaci in this study. Among the insecticides tested as soil applications (drenches), lower 
survival of $T$. tabaci was recorded for carbofuran, whereas methomyl was less effective. These products traditionally are applied as a soil drench or foliar application, respectively (55). The duration of efficacy of both insecticides was significantly shorter than previously reported. When applied as a soil drench in the field, carbofuran is reported to offer protection of tobacco plants against thrips for 50 to $55 \mathrm{dpa}$ and methomyl for $25 \mathrm{dpa}$; subsequent sprays, if needed, are suggested 1 month after application (55). The results of this study underline the need to reconsider old recomendations for these insecticides when used against $T$. tabaci in tobacco crops in Greece.

Although not registered for thrips control, imidacloprid was included in this study because it has completely replaced other soil-applied insecticides for control of thrips in tobacco in many areas in Greece (E. K. Chatzivassiliou, unpublished), due to its excellent and long-lasting residual efficacy against aphids (49) when applied only as a soil drench at transplanting (24). Imidacloprid applications to soil reduced the spread of $F$. fusca and TSWV incidence $(17,25)$ but foliar applications did not provide good thrips control in other studies (42). Imidacloprid was not effective against $T$. tabaci in this study, probably due to the use of a significantly lower dose than the dose used against $F$. fusca $(17,25)$. Field observations also showed that imidacloprid applied at the rate used to control aphids in tobacco did not effectively protect tobacco plants against T. tabaci and TSWV (E. K. Chatzivassiliou, unpublished). Interestingly, an increased number of thrips males was observed among offspring of females surviving on leaves of carbofuran- and imidacloprid-treated plants. Increased production of males is a mechanism by which thrips overcome unfavorable conditions (32) and has been associated with selection of insecticide-resistant thrips populations (31). T. tabaci populations can develop resistance to pyrethroids or organophosphorus insecticides, as recorded in Canada and New Zealand $(33,35)$.

The pyrethroid cypermethrin and the oranophosphorus insecticides methamidophos and dimethoate showed the best efficacy against $T$. tabaci among six foliarapplied insecticides evaluated in this study. Cypermethrin provided protection of tobacco plants against $T$. tabaci up to $10 \mathrm{dpa}$, even under field conditions. This high efficacy possibly could be due to the fact that these insecticides, mainly pyrethroids, rarely have been used on tobacco in the Kilkis prefecture prior to this study, although they are registered for use in tobacco crops.

In Greece, insecticide spray programs in tobacco have been based on fixed time intervals between applications regardless of the size of thrips populations (55). In this study, field data determining virus spread were used to coordinate insecticide applications and to set the dates of application. Several studies have shown that the presence and spread of TSWV in tobacco is strongly correlated with fluctuations in thrips populations $(21,37)$, whereas studies in tomato have associated thrips dispersal and TSWV management (39). However, the spread and transmission of TSWV are better correlated with the population size of thrips and the percentage of viruliferous individuals $(1,46,57,59)$. In this study, the presence of thrips and the increase from 5 to $52 \%$ in percentage of viruliferous thrips determined the timing of the first insecticide applications in tobacco seedbeds. The high numbers of thrips constantly trapped in the control field after transplantation was the reason for immediate and frequent foliar-insecticide applications to cover the susceptible stage of the plants until the end of June. Afterward, applications were performed when thrips attacks were recorded on the tobacco plants.

The thrips and TSWV control scheme applied in this study was aimed at locating and reducing inoculum of TSWV (i.e. viruliferous thrips). The destructive TSWV epidemic that occurred in this area the previous cropping season resulted in the development of large and highly viruliferous thrips populations (E. K. Chatzivassiliou, unpublished). The surviving thrips from these large populations could initiate a new epidemic, even in the absence of other virus sources. Thrips may overwinter as adult females on plants or as pupae in the soil (32); T. tabaci overwintering females have been recorded in other studies in cereal crops and on winter weeds $(16,29,50)$. In this study, T. tabaci overwintering individuals were not found
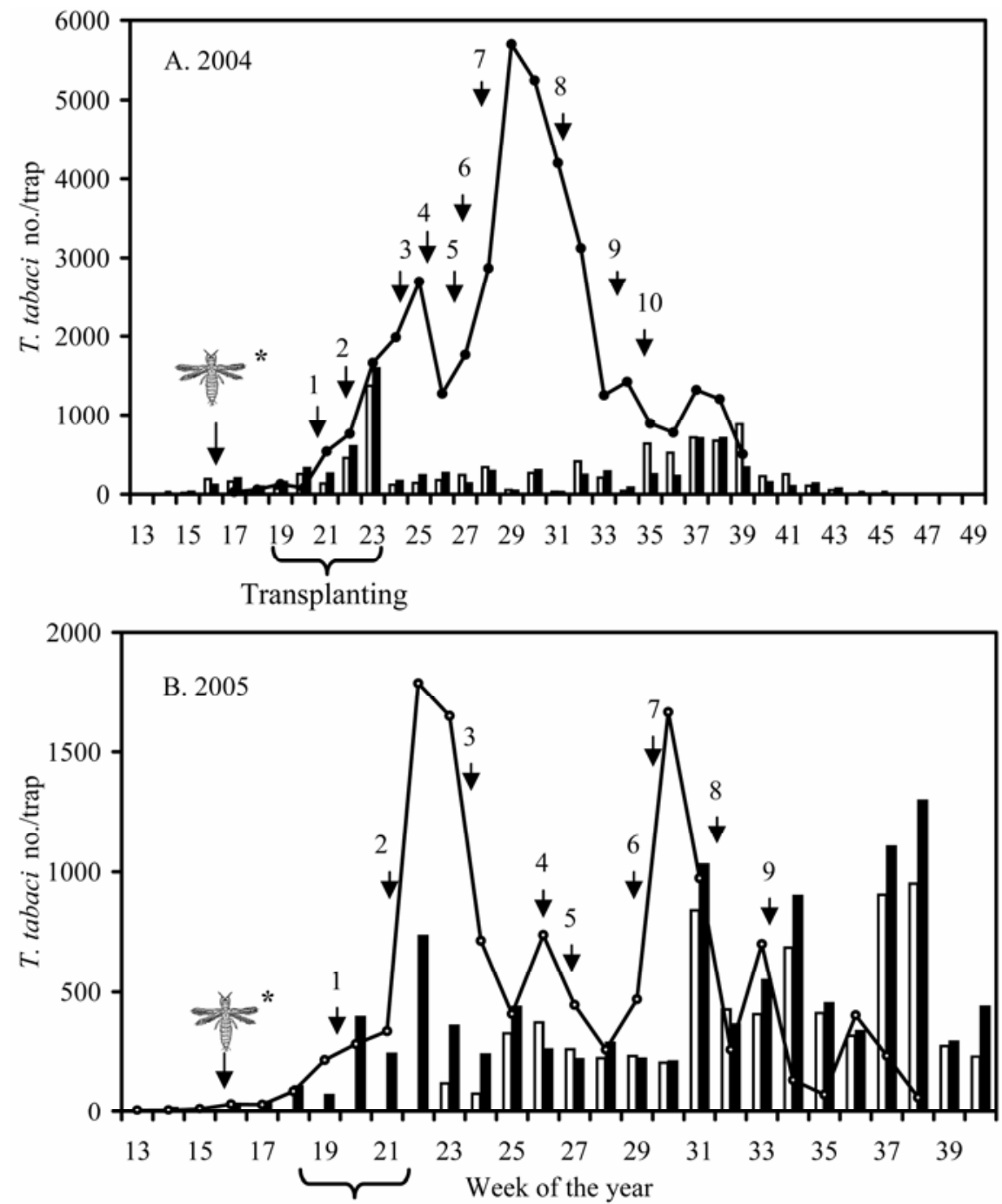

Transplanting of seedlings

Fig. 4. Mean number of Thrips tabaci adults trapped on blue sticky traps in Nicotiana tabacum cv. Virginia crops (white columns) or neighboring flora (black columns) in A, 2004 and B, 2005. Lines represent the $T$. tabaci numbers recorded in a crop of an oriental tobacco cultivar used as a control treatment (black dots). Arrows indicate the dates at which insecticides were applied: $1=$ carbofuran applied during transplanting; 2, 5, and $8=$ methomyl; 3 and $6=$ cypermethrin; and 4, 7, 9, and $10=$ malathion sprays. The asterisk and thrips drawing indicate detection of the first viruliferous thrips on weed plants in the fields. 
on the plant material sampled and evaluated, but they emerged from the soil sampled at the end of winter from the field borders in which weeds were growing.

The observation that T. tabaci individuals overwintered in the soil sampled in this study implies that thrips can dwell for some time between two consecutive cropping seasons on weed flora. Thrips flight records and weed samplings in this study supported this assumption. A significant number of T. tabaci adults was recorded on traps placed over weeds in fields before transplanting tobacco seedlings (up to 390 thrips in week 20 of 2004 and 2005) and after the end of tobacco harvest (150 thrips in week 40 of 2004 and 230 thrips in week 39 of 2005). Although thrips were found on tobacco stalks left after harvest, sampling showed that T. tabaci could spend at least one generation on weeds at the beginning of the following season. Weeds can serve as a source of inoculum of TSWV for acquisition by thrips or become infected with TSWV by those thrips. Perennial weeds such as Cardaria draba and annual winter weeds such as Chamomila recutita were found infected with TSWV and infested by viruliferus $T$. tabaci very early in the season. The role of weeds as a source of TSWV inoculum for nearby crops has been recognized for $T$. tabaci and tobacco (11) and for other thrips vectors and crop combinations $(3,6,15,22$, 26-28,52). The presence of significantly lower number of thrips in greenhouse float systems compared with open-air soil seedbeds in this study demonstrated that neighboring vegetation affects thrips population dynamics in tobacco seedbeds in Greece.

Adult thrips feeding on weeds will disperse into and within a crop when disturbed by human activities (53), wind, or maturity and wilting of the weeds $(2,5,51)$. The first thrips population peak in this study was observed at the end of June, when cereals were close to maturity. During the thrips samplings in this study, $T$. tabaci was not found on wheat, but high populations were found on weeds within cereal fields. These thrips will disperse when disturbed by harvest of the cereals and may contribute to the sudden increase in thrips population size recorded from late July to early August in tobacco fields. The spread of TSWV is considered to be monocyclic, with limited secondary spread in most crops, particularly those crops with short growing seasons (30). Although the tobacco growing season is long enough to support several T. tabaci generations, limited secondary spread of TSWV has been recorded in Greece (13), possibly due to the high preference of $T$. tabaci for tobacco (11). Under these conditions, migrating viruliferous thrips originating from weed flora form the primary inoculum for nearby tobacco seedbeds or fields.
Coutts and his colleagues pointed out the significance of nearby virus sources for the spread of TSWV in lettuce and pepper crops (18). An abundance of natural weed flora is always found near tobacco crops in Greece (8) and potentially can represent TSWV sources for thrips spread in tobacco crops $(11,30)$. Viruliferous thrips infesting weeds were first caught in mid-April and increased in numbers thereafter. Those thrips then can disperse to tobacco plants once transplanted into the fields, or in seedbeds located close to the fields, as shown by the trap plants evaluated in this study. To protect tobacco seedlings against migrating thrips, methomyl applications were carried out in the seedbeds followed by malathion application before transplantating. To reduce the risk of exposing young seedlings to further viruliferous thrips, strips of weeds surrounding the fields or seedbeds also were sprayed with insecticides when the crops were sprayed. This thrips management scheme also included an insecticide application to wild flora surrounding the fields before transplantating; among the insecticides tested, malathion was used for these applications due to its short REI and low toxicity to farmers (14).

Weed samples and trap records showed that the transplanted tobacco seedlings were in the danger of being infested by a high number of thrips $(340 \pm 160$ thrips recorded on the traps in 2004 and $230 \pm$ 130 in 2005 , mean $+\mathrm{SD}, n=10$ ), many of them viruliferous. However, the tobacco seedlings could not be sprayed until they recovered from the transplanting shock (10 to 15 days); therefore, an application before transplanting of an insecticide with high efficacy against thrips and long residual activity is needed. Drenching of lettuce seedlings with neonicotinoid insecticides effectively suppressed TSWV (17). Applying such insecticides in the seedbed (55) was avoided in this scheme in order to protect the farmers handling the plants during transplanting. Instead, a systemic insecticide was applied to the seedlings as a soil drench directly after transplanting. The use of systemic, soil-applied insecticides can suppress thrips population development effectively (30), possibly due to a better distribution of the insecticide in plants compared with foliar spray (39). Thrips can infect tobacco with TSWV by short feeding probes of only $5 \mathrm{~min}$ (42). The risk of successful TSWV transmission, but also of insecticide accumulation in the thrips, increases with successive punctures. Ingestion of the lethal insecticide dose after several to many feeding probes may explain the difficulty in eliminating direct spread of TSWV by thrips control. The first thrips population peak was recorded a week after the end of transplantation in 2004 and 2005. The data on the thrips population could be used further to evaluate planting dates as a possible control measure to avoid exposure of young plants to peak thrips populations (30). This measure is of major importance for the spread of TSWV in groundnut (20).

The use of soil-applied insecticides, such as carbofuran, can suppress final TSWV incidence effectively in flue-cured tobacco only when followed by foliarapplied insecticides (37). A significant increase in $T$. tabaci numbers was observed in the first month after transplanting tobacco in this study, which occurred in the stage of the plants most susceptible to TSWV infection $(34,36,55)$; hence, this period in tobacco production is critical for virus spread. Cypermethrin, a pyrethroid with characteristic thrips anti-feeding activity (43), effectively protected tobacco seedlings from thrips and TSWV in this period, when applied 2 weeks after drenching with carbofuran.

In general, the intervals between insecticide applications chosen in this scheme were shorter than the residual activity recorded in the laboratory experiment. This was because it is likely that the protective effect of the insecticides may be shorter under field applications compared with the laboratory experiment and with higher thrips populations. Traditional programs applied for the control of thrips and TSWV in tobacco in Greece recommend no applications of insecticides or a few sprays within 1 month after transplanting seedlings (55). The decreased (relative to that reported in the traditional insecticide application programs) residual activity we recorded for the soil-applied insecticides during this critical period may explain the poor efficacy of those programs to effectively control spread of the virus (13).

A major component of the insecticide application scheme evaluated in this study was the large-scale application of foliarapplied insecticides and, as a result, a significant reduction in TSWV incidence and of crop losses compared with uncoordinated applications by individual farmers in the past. The control measures were applied by more than 300 farmers to 1,000 ha in 2004 but to only 500 ha by 100 farmers in 2005, due to the tempered enthusiasm of growers raised by expected restrictions in tobacco cultivation in the European Union. Although host plant resistance remains the most promissing control measure (30), the use of reflective mulches (48), avoiding succesive side-byside planting, or isolating crops from nearby infected weeds or crops $(14,18$, $30,39)$ are major components of any management effort but not applicable to tobacco crops in Greece. The application of chemical control measures over large areas minimizes TSWV spreading from adjacent untreated but infected to healthy crops $(18,20)$ and, therefore, can be an efficient way to combat virus epidemics. Cooperation of farmers in most of the control mea- 
sures applied is essential for the success of managing TSWV (14). The use of epidemiological data to coordinate applications against TSWV vectors significantly decreased the number of applications suggested by the traditionally applied control schemes (55) from about 15 to less that 10. Data concerning thrips population fluctuation can be evaluated further in determining the effect of transplantation dates on the TSWV infection (20) or to develop TSWV forecasting $(14,60)$ The use of agrochemicals that elicit systemic acquired resistance such as acibenzolar-S-methyl (19) in combination with thrips population data may result in an even more efficient and environmentally friendly approach for managing TSWV infections in tobacco crops.

\section{ACKNOWLEDGMENTS}

I thank the Tobacco Growers Association of Toumba (Paionia, Kilkis prefecture) for excellent collaboration in this study, and taking over the cost of this publication; the Union of Agricultural Cooperatives of Axioupolis for their participation in the first year of this study; P. Alexiadis for his assistance in collecting thrips and plant material; D. Peters Laboratory of Virology, Agricultural University of Wageningen, The Netherlands) for the antisera against TSWV (BR-01); and an unknown referee for his/her considerable help.

\section{LITERATURE CITED}

1. Aramburu, J., Riudavets, J., Arno, J., Lavina, A., and Moriones, E. 1996. The proportion of viruliferous individuals in field populations of Frankliniella occidentalis: implications for tomato spotted wilt virus epidemics in tomato. Eur. J. Plant Pathol. 103:623-629.

2. Bailey, S. F. 1935. Thrips as vectors of plant disease. J. Econ. Entomol. 28:856-863.

3. Bautista, R. C., Mau, R. F. L., Ullman, D. E., and Custer, D. M. 1995. Potential of Tomato spotted wilt tospovirus plant hosts in Hawaii as virus reservoirs for transmission by Frankliniella occidentalis (Thysanoptera: Thripidae). Phytopathology 85:953-958.

4. Carrasco, G., Rebolledo, P., and Valverde, P. 2000. Floating system: an alternative for producing tobacco transplants in Chile. Acta Hortic. 517:241-246.

5. Carter, W. 1939. Population of Thrips tabaci, with special reference to virus transmission. J. Anim. Ecol. 8:261-276.

6. Chamberlin, J. R., Todd, J. W., Beshear, R. J., Culbreath, A. K., and Demski, J. W. 1992. Overwintering hosts and wingform of thrips, Frankliniella spp., in Georgia (Thysanoptera: Thripidae): implications for management of spotted wilt disease. Environ. Entomol. 21:121-128

7. Chatzivassiliou, E. K. 2002. Thrips tabaci: an ambiguous vector of TSWV in perspective. Pages 69-75 in: Thrips and Tospoviruses: Proc. 7th Int. Symp. Thysanoptera. R. Marullo and L. Mound, eds. Australian National Insect Collection, Canberra, Australia.

8. Chatzivassiliou, . K., Efthimiou, K., Drossos, E., Papadopoulou, A., Poimenidis, G., and Katis, N. I. 2004. survey of tobacco viruses in tobacco crops and native flora in Greece. Eur. J. Plant Pathol. 110:1011-1023.

9. Chatzivassiliou, E. K., Mpoumpourakas, I., Drossos, E., Eleftherohorinos, I., Jenser, G., Peters, D., and Katis, N. I. 2001. Differential Tomato spotted wilt virus infection and vector species infestation of weeds in greenhouses and tobacco fields. Plant Dis. 85:40-46.
10. Chatzivassiliou, E. K., Peters, D., and Katis, N. I. 2002. The efficiency by which Thrips tabaci populations transmit Tomato spotted wilt virus depends on their host preference and reproductive strategy. Phytopathology 92:603-609.

11. Chatzivassiliou, . K., Peters, D., and Katis, N. I. 2007. The role of weeds in the spread of Tomato spotted wilt virus by Thrips tabaci (Thysanoptera: Thripidae) in tobacco crops. J. Phytopathol. 11:699-705.

12. Chatzivassiliou, E. K., Weekes, R., Morris, J., Wood, K. R., Barker, I., and Katis, N. I. 2000. Tomato spotted wilt tospovirus in Greece: its incidence following the expansion of Frankliniella occidentalis, and characterization of isolates collected from various hosts. Ann. Appl. Biol. 137:127-134.

13. Chatzivassiliou, E. K., Zintzaras, E., Jenser, G., and Katis, N. I. 1999. Temporal and spatial spread of tomato spotted wilt tospovirus (TSWV) in relation to thrips populations in tobacco crops in Northern Greece. Pages 106107 in: Plant Virus Epidemiology: Current Status and Future Prospects. Proc. 7th Int. Virus Epidemiol. Symp. A. Fereres, J. M. Thresh, and M. Irwin, eds. Aguadulce (Almeria), Spain.

14. Cho, J. J., Mau, R. F. L, German, T. L., Hartmann, R. W., Yudin, L. S., Gonsalves, D., and Provvidenti, R. 1989. A multidisciplinary approach to management of Tomato spotted wilt virus in Hawaii. Plant Dis. 73:375-383.

15. Cho, J. J., Mitchell, W. C., Mau, R. F. L., and Sakimura, K. 1987. Epidemiology of Tomato spotted wilt virus disease on crisphead lettuce in Hawaii. Plant Dis. 71:505-508.

16. Cho, K., Eckel, C. S., Walgenbach, J. F., and Kennedy, G. G. 1995. Overwintering of thrips (Thysanoptera: Thripidae) in North Carolina. Environ. Entomol. 24:58-67.

17. Coutts, B. A., and Jones, R. A. C. 2005. Suppressing spread of Tomato spotted wilt virus by drenching infected source or healthy recipient plants with neonicotinoid insecticides to control thrips vectors. Ann. Appl. Biol. 146:95103.

18. Coutts, B. A., Thomas-Carroll, M. L., and Jones, R. A. C. 2004. Patterns of spread of Tomato spotted wilt virus in field crops of lettuce and pepper: spatial dynamics and validation of control measures. Ann. Appl. Biol. 145:231245 .

19. Csinos, A. S, Pappu, H. R., McPherson, R. M., and Stephenson, M. G. 2001. Management of Tomato spotted wilt virus in flue-cured tobacco with acibenzolar-S-methyl and imidacloprid. Plant Dis. 85:292-296.

20. Culbreath, A. K., Todd, J. W., and Brown, S. L. 2003. Epidemiology and management of tomato spotted wilt in peanut. Annu. Rev. Phytopathol. 41:53-75.

21. De Borbón, C. M., Cracia, O., and Piccolo, R. 2006. Relationships between tospovirus incidence and thrips populations on tomato in Mendoza, Argentina. J. Phytopathol. 154:9399

22. Doederlein, T. A., and Sites, R. W. 1993. Host plant preferences of Frankliniella occidentalis and Thrips tabaci (Thysanoptera: Thripidae) for onions and associated weeds on the Southern high plains. J. Econ. Entomol. 86:17061713.

23. Goldbach, R. W., and Peters, D. 1994. Possible causes of the emergence of Tospovirus diseases. Sem. Virol. 5:113-120.

24. Giannopolitis, K. N. 1994. Plant Protection Product 1995. AgroTypos SA Press, Athens, Greece.

25. Groves, R. L., Sorenson, C. E., Walgenbach, J. F., and Kennedy, G. G. 2001. Effects of imidacloprid on transmission of Tomato spotted wilt tospovirus to pepper, tomato and tobacco by Frankliniella fusca Hinds (Thysanoptera: Thripidae). Crop Prot. 21:439-445.
26. Groves, R. L., Walgenbach, J. F., Moyer, J. W and Kennedy, G. G. 2001. Overwintering of Frankliniella fusca (Thysanoptera: Thripidae) on winter annual weeds infected with Tomato spotted wilt virus and patterns of virus movement between susceptible weed hosts. Phytopathology 91:891-899.

27. Groves, R. L., Walgenbach, J. F., Moyer, J. W., and Kennedy, G. G. 2002. The role of weed hosts and tobacco thrips, Frankliniella fusca in the epidemiology of Tomato spotted wilt virus. Plant Dis. 86:573-582.

28. Hobbs, H. A., Black, L. L., Story, R. N., Valverde, R. A., Bond, W. P., Gatti, J. M. Schaeffer, D. O., and Johnson, R. R. 1993. Transmission of Tomato spotted wilt virus from pepper and three weed hosts by Frankliniella fusca. Plant Dis. 77:797-799.

29. Jenser, G., Gáborjányi, R., Szénási, A., Almási, A., and Grasselli, M. 2003. Significance of hibernated Thrips tabaci Lindeman (Thysanoptera, Thripidae) adults in the epidemic of tomato spotted wilt virus. J. Appl. Entomol. 127:7-11

30. Jones, R. A. C. 2004. Using epidemiological information to develop effective integrated virus disease management strategies. Virus Res. 100:5-30.

31. Kendall, D. M., and Capinera, J. L. 1990 Geographic and temporal variation in the sex ratio of onion thrips. South. Entomol. 15:8088.

32. Lewis, T., 1973. Thrips-Their Biology, Ecology and Economic Importance. Academic Press, New York.

33. MacIntyre Allen, J. K., Scott-Dupree, C. D., Tolman, J. H., and Ron Harris, C. 2005. Resistance of Thrips tabaci to pyrethroid and organophosphorus insecticides in Ontario, Canada. Pest Manage. Sci. 61:809-815.

34. Mandal, B., Wells, M. L., Martinez-Ochoa, N., Csinos, A. S., and Pappu, H. R. 2007. Symptom development and distribution of Tomato spotted wilt virus in flue-cured tobacco. Ann. Appl. Biol. 151:67-75.

35. Martin, N. A., Workman, P. J., and Butler, R. C. 2003. Insecticide resistance in onion thrips (Thrips tabaci) (Thysanoptera: Thripidae). N. Z. J. Crop Hortic. Sci. 31:99-106.

36. McPherson, R. M. 2006. Incidence of thrips and Tomato spotted wilt tospovirus in fluecured tobacco protected from early season insect pest infestation. J. Econ. Entomol. 99:764770.

37. McPherson, R. M., Beshear, R. J., and Culbreath, A. K. 1992. Seasonal abundance of thrips (Thysanoptera: suborders Terebrantia and Tubulifera) in Georgia flue-cured tobacco and impact of management practices on the incidence of Tomato spotted wilt virus. J. Entomol. Sci. 27:257-268.

38. McPherson, R. M., Pappu, H. R., and Jones, D. C. 1999. Occurrence of five thrips species on flue-cured tobacco and impact on spotted wilt disease incidence in Georgia. Plant Dis. 83:765-767.

39. Nault, B. A., Speese, J., III, Jolly, D., and Groves, R. L. 2003. Seasonal patterns of adult thrips dispersal and implications for management in eastern Virginia tomato fields. Crop Prot. 22:505-512.

40. Palmer, J. M., Mound, L. A., and Heaume, J. du. G. 1989. CIE Guides to Insects of Importance to Man: 2. Thysanoptera. C.A.B. International, London.

41. Pappu, H. R., Csinos, A. S., McPherson, R M., Jones, D. C., and Stephenson, M. G. 2000 Effect of acibenzolar-S-methyl and imidacloprid on suppression of Tomato spotted wilt Tospovirus in flue-cured tobacco. Crop Prot. 19:349-354.

42. Parrella, G., Gognalons, P., Gebre-Selassie, K. Vovlas, C., and Marcou, G. 2003. An update of the host range of Tomato spotted wilt virus. J. 
Plant Pathol. 85:227-264.

43. Perring, T. M., Gruenhagen, N. M., and Farrar, C. A. 1999. Management of plant viral diseases through chemical control of insect vectors. Annu. Rev. Entomol. 44:457-481.

44. Peters, D. 2004. Tospoviruses: a threat to intensive agriculture in the tropics. Pages 719-742 in: Virus and Virus-like Diseases of Major Crops in Developing Countries. G. Loebenstein and G. Thottapilly, eds. Kluwer Academic Publisher, Dordrecht, The Netherlands.

45. Peters, D., Wijkamp, I., van de Wetering, F., and Goldbach, R. 1996. Vector relations in the transmission and epidemiology of tospoviruses. Acta Hortic. 431:29-43.

46. Puche, H., Berger, R. D., and Funderburk, J. E. 1995. Population dynamics of Frankliniella species (Thysanoptera: Thripidae) and progress of spotted wilt in tomato fields. Crop Prot. 14:577-583.

47. Reddy, D. V. R., Amin, P. W., McDonald, D., and Chanekar, A. M. 1983. Epidemiology and control of groundnut bud necrosis and other diseases of legume crops in India caused by Tomato spotted wilt virus. Pages 93-102 in: Plant Virus Epidemiology. R. T. Plumb and J. M Thresh, eds. Blackwell Scientific Publications, Oxford.
48. Riley, D. G., and Pappu, H. R. 2000. Evaluation of tactics for management of thripsvectored Tomato spotted wilt virus in tomato. Plant Dis. 84:847-852.

49. Rudolph R. D., and Rogers, W. D. 2001. The efficacy of imidacloprid treatment for reduction in the severity of insect vectored virus diseases of tobacco. Pflanzenschutz-Nachr. Bayer (Ger. Ed.) 54:311-336.

50. Sakimura, K. 1932. Life history of Thrips tabaci L. on Emilia sagittata and its host plant range in Hawaii. J. Econ. Entomol. 25:884891.

51. Sakimura, K. 1961. Field observations on the thrips vector species of the Tomato spotted wilt virus in the Sao Paolo area, California. Plant Dis. Rep. 45:772-776.

52. Stobbs, L.W., Broadbent, A. B., Allen, W. R., and Stirling, A. L. 1992. Transmission of Tomato spotted wilt virus by the western flower thrips to weeds and native plants found in Southern Ontario. Plant Dis. 76:13-29.

53. Thresh, J. M. 1981. The role of weeds and wild plants in the epidemiology of plant virus diseases. Pages 53-70 in: Pests, Pathogens and Vegetation. J. M. Thresh, ed. Pitman Scientific Publications, London.

54. Todd, J. W., Culbreath, A. K., and Brown, S. L. 1996. Dynamics of vector populations and progress of spotted wilt disease relative to insecticide use in peanuts. Acta Hortic. 431:483490.

55. Tsakiridis, J. P. 1980. Tomato spotted wilt virus on tobacco in Greece: epidemiology and control. Pages 34-36 in:. Proc. 5th Mediterr. Phytopathol. Union Congr.. Patra, Greece.

56. Tsakiridis, J. P., and Gooding, G. V., Jr. 1972 Tomato spotted wilt virus in Greece. Phytopathol. Mediterr. 11:42-47.

57. Ullman, D. E., Cho, J. J., Mau, R. F. L., Hunter, W. B., Westcott D. M., and Custer, D. M. 1992. Thrips-tomato spotted wilt virus interaction: morphological, behavioural and cellular components influencing thrips transmission. Adv. Dis. Vector Res. 9:195-240.

58. Whitfield, A. E., Ullman, D. E., and German, T. L. 2005. Tospovirus-thrips interactions. Annu. Rev. Phytopathol. 43:459-489.

59. Wijkamp, I., and Peters, D. 1993. Determination of the median latent period of two tospoviruses in Frankliniella occidentalis, using a novel leaf disk assay. Phytopathology 82:986991.

60. Yudin, L. S., Tabashnik, B. E., Cho, J., and Mitchel, W. C. 1990. Disease-prediction and economic models for managing Tomato spotted wilt virus disease in lettuce. Plant Dis. 74:211-216. 